\title{
Comparative Analysis of Copybooks used in the Czech Republic
}

\author{
Iva Košek Bartošová, Anna Plovajková, Tereza Podnecká \\ University of Hradec Králové, Faculty of Education, Rokitanského 62, 50003 Hradec Králové, Czech Republic
}

\begin{abstract}
The proposed research project is a follow-up of a specific research project realized in 2014 and designed to identify the publishing houses having the greatest numbers of sales of textbooks for $1^{\text {st }}-3^{\text {rd }}$ grades of primary schools as well as the reasons for which teachers chose the materials from a particular publishing house in the Czech Republic.

The purpose of the present project is a qualitative comparison of the most widely used copybooks in the Czech Republic using comparative analysis (content, graphical design, format, adequacy of the tasks etc.). The research scheduled for the next term is going to deal with similar analyses of copybooks (including the type of script) in selected countries around the world.
\end{abstract}

Index Terms - Elementary literacy; reading literacy, workbooks; research

\section{Introduction}

In the context of the curricular documents in European countries [1] the principal common trend in the development of literacy is the focus on the period of development of prereading skills, i.e. language and communication skills, visual and auditory perceptions, correction of speech defects, the development of motor and graphomotor skills, cognitive and mental processes etc. [2] The issue is extremely complicated and connected with a crucial process as well as a crucial stage of the child's development, namely the pre-primary and primary education and the area of elementary reading and writing skills, i.e. the stage on which the child learns letters and the formation of syllables and words. S/he gradually forms reading habits, automates them, learns to understand the written text and simultaneously acquires writing skills.

Unlike countries such as China (where one of the oldest writing systems (a logographic script) originated) European countries have phonetic scripts based on the Greek alphabet. It has been mentioned that a previous research project (2014) focused only on one area of the development of literacy skills in children in $1^{\text {st }}-3^{\text {rd }}$ grade of primary schools, evaluating textbooks (primers and readers) and copybooks published and used in schools in the Czech Republic. We intend to use the data obtained through the last year research and make a comparative analysis of the most widely used copybooks in the Czech Republic (printed by the publishing houses Nová škola, Alter, Fraus, Studio 1+1, Didaktis), focusing on their content, graphic design, format, adequacy of the texts and space for the needs of pupils with early writing skills.

\section{Theoretical Basis}

The research on textbooks (workbooks) around the world generally has a strong position among other researches. It is highly developed, especially in Germany, Japan, and the USA and in the Scandinavian countries, which have establishments specializing in textbooks. Many of them even publish their own journals. In France there is even a Special centre for information on school textbooks, maintaining a database of all French textbooks published since 1789 [3].

An international coordination and information base for all countries is provided, among others, by IARTEM (International Association for Research on Textbooks and Educational Media). It organises an international conference every two years. The last one was held in September 2013 in Ostrava in the Czech Republic and its title was: Textbooks and Educational Media and the next one is going to take place in Berlin, Germany in the year 2015.

In the Czech Republic, the issue is the domain of the "Skupina pro výzkum kurikula (Curriculum research group)" at the Institute of Research for School Education of the Faculty of Education at Masaryk University (IRSE) focussing on the quality and evaluation criteria of textbooks. The theoretical issues from this domain as well as evaluation criteria can be found in publications by Maňák, Knecht, Janík [4] [5] .

There has been little interest so far in the area of workbooks - copybooks in the Czech Republic. The data obtained here will be useful for orientation on the market and bring new information to pedagogues, parents as well as student teachers of teaching at primary schools.

The current trend of proliferation of textbooks and publishing houses producing primers, readers, workbooks and copybooks for children results in a kind of chaos and confusedness of our market and, importantly, poor orientation of the teacher selecting the best material for children in the first year of primary schools. This is why we decided to describe the situation at Czech schools as to which copybooks are used in the first year and complement it with an analysis of the used script and material [6].

\section{Research Objectives and Methods}

The purpose of the research was to analyse the most widely used copybooks - textbooks in the Czech Republic based on adapted evaluation criteria (originally presented by Maňák, Knecht), focusing on the content, graphic design, format and the kind of writing tasks. We further examined the reasons for which teachers chose the particular copybooks produced by selected publishing houses (based on the results of the questionnaire survey). 


\section{A. Research Sample}

The research sample is represented by the data concerning the used workbooks and copybooks and obtained through questionnaire survey in 2014, in which 614 respondents primary school teachers were involved. The most widely used copybooks were published by Nová škola, Alter, Fraus, Studio 1+1, Didaktis, SPN (Prodos).

\section{B. Methods and Techniques}

The method of comparative analysis will be used. Comparative analysis is based on comparing the qualities of two different phenomena / works / systems etc. and it is applicable in various fields such as sociology, political science, economy, literary science or pedagogy and others, the specific procedures being slightly different in each field. The methods of analysing workbooks - copybooks in the first year of primary schools will be based on evaluation criteria focussing on:

a) Content

b) Graphic design

c) Format (size)

d) Diversity of texts (adequacy, types of writing tasks)

e) The number of different copybooks for first graders produced by the same publishing house

The research project works with data obtained through a questionnaire survey based on a non-standardized questionnaire, which is one of the most common research tools in pedagogy, psychology, demography and other fields [7].

For the purpose of this article, we will be using the part of results based on the second half of the questionnaire concerning exercise books and workbooks for elementary writing (copybooks).

The prepared on-line questionnaires were filled in by respondents contacted through social networks (facebook.com, twiter.com...), or by email. The total return of the questionnaires was 614 , i.e. $89 \%$. The questionnaire was statistically processed in MS Excel 2010.

\section{Results of Comparative Analysis}

The specific research realized in 2014 brought information on the most widely used copybooks in the Czech Republic (Fig 1). According to our respondents, the most widely used copybooks as well as textbooks are produced by the following publishing houses: Nová škola (49 \%), Alter (14\%), Fraus (7\%), Studio 1+1 (7\%), Didaktis (6\%), SPN (4\%) and Prodos (3\%). The most common reason for the selection of copybooks ( $26 \%$ of respondents) was that they were published by the same house as the textbook (Fig. 2). Other reasons include content and didactic qualities and range and graphic design. Regrettably, $7 \%$ of pedagogues are not free to choose a particular copybook themselves.

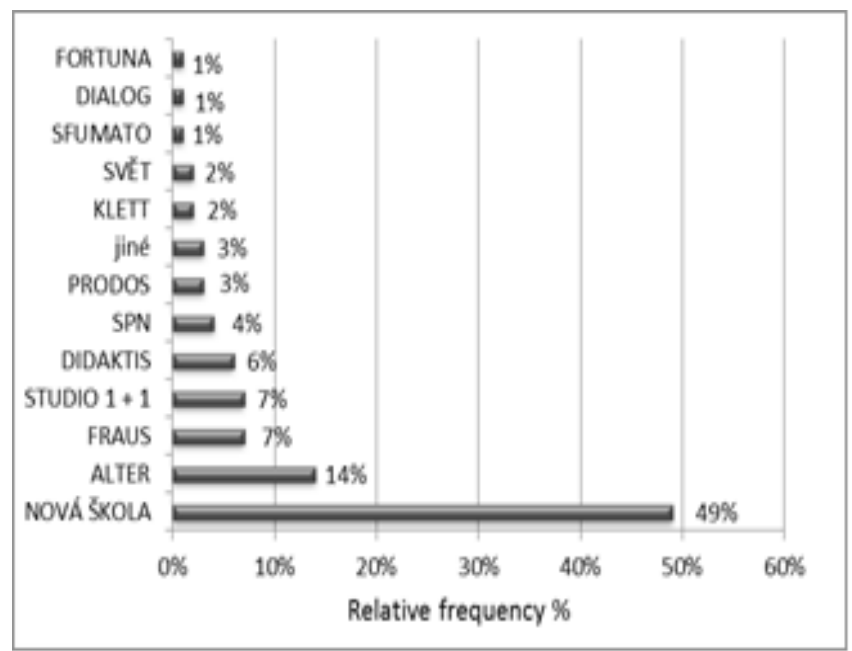

Fig. 1 Publishing houses of workbooks for teaching elementary writing

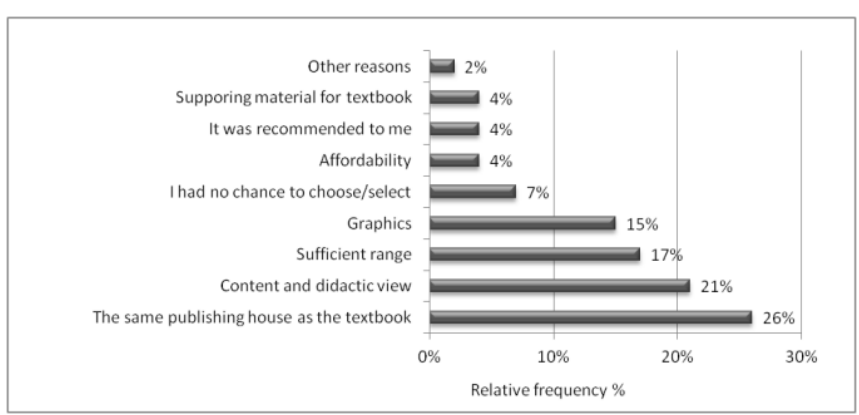

Fig. 2 Reasons for selecting workbooks for teaching elementary writing

Building on the results of previous research, we decided to compare the most widely used copybooks in the Czech Republic as to their content and format. We focussed mainly on their size, the number of copybooks produced by the same publishing house, average number of pages in the given edition and diversity of texts (types of writing tasks).

The differences in size of the individual copybooks as well as the numbers of volumes in one edition captured our attention at the first sight. In order to make the presentation of results more systematic, we kept the copybooks ordered according to popularity (Fig. 3).

Nová škola has five workbooks one of which has A4 format $(210 \times 297 \mathrm{~mm})$ - relaxation exercises while the remaining four have A5 format (148 x 210). Similarly, the publishing house Alter has a book of relaxation exercises in A4 format (Fig. 4) . The remaining three copybooks have A5 format. The publishing house Fraus is unique in having only one format in the edition, which is smaller than A4 (195 x 260 $\mathrm{mm})$.

The edition of Studio $1+1$ is identical to that of Nová škola. The booklet with relaxation exercises is in A4 format and the remaining four copybooks in A5. The publishing house Didaktis prints a booklet with relaxation exercises in A4 format and three more copybooks in A5. The publishing house SPN uses A5 format for all the five copybooks in the edition. The last edition of copybooks prepared by Prodos has five 
parts and an atypical format (200x $260 \mathrm{~mm})$. Figure 4 makes it evident that Nová škola, Alter, Studio 1+1 and Didaktis print only one workbook of elementary writing in A4 format. Publishing houses Fraus and Prodos opted for a unified format similar to A4 in size.

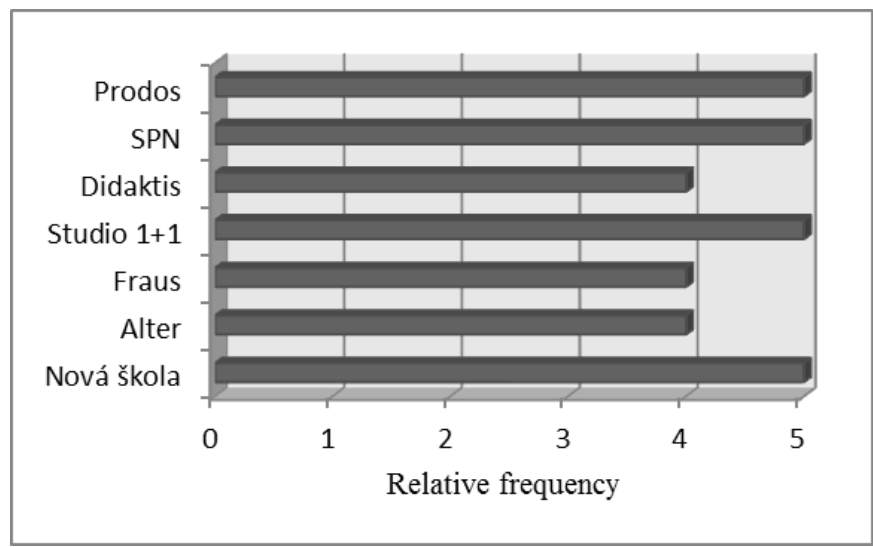

Fig. 3 The number of volumes in the edition

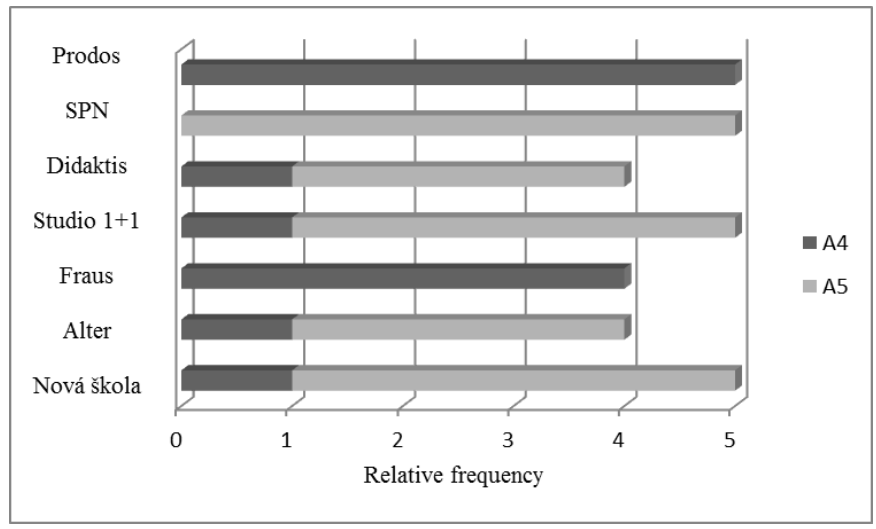

Fig. 4 Size - format of the copybooks

An interesting fact is the difference in the number of pages in the individual copybooks in the set. In case of Nová škola it is the relaxation exercises which are the most voluminous part, the average number of pages is 38 . Both alter and Fraus have all parts with an identical number of pages (32). Similarly, the copybooks of SPN all have 24 pages. The average page count of copybooks by both Studio $1+1$ and Prodos is 29. Unlike in the case of Nová škola, the relaxation exercise book published by Didaktis has fewer pages than the remaining booklets, the average page count being 44 (see figure 5).

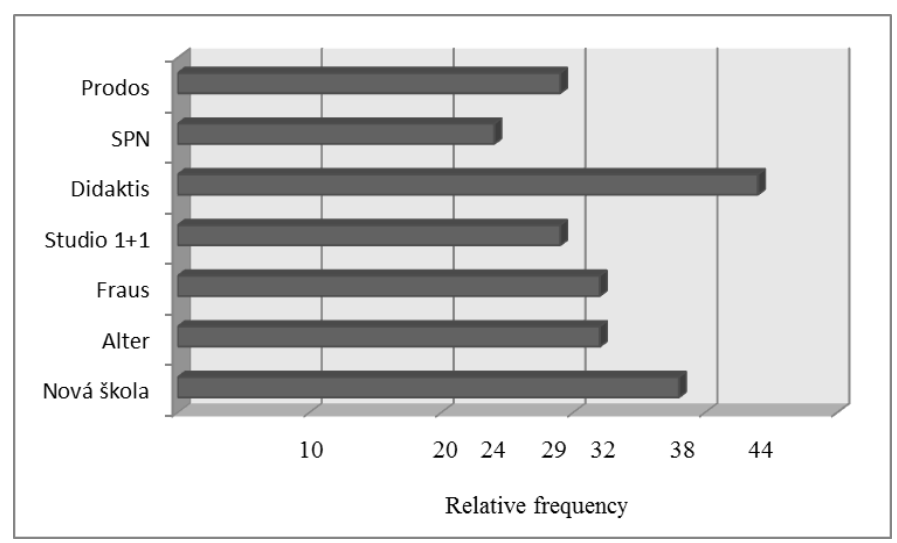

Fig. 5 Average page count in the edition

A difficult part of the research was the comparative analysis of the types of exercises in the copybooks. The most frequent activities in the first year are copying (copying the letters preserving their exact shape) and transcription (transcribing the printed script into cursive script). None of the publishing houses has more than $25 \%$ of transcription exercises. The greatest space for transcription is provided by Studio 1+1. Contrarily, it is Fraus who has the lowest percentage. Despite the diversity of the tasks, there are only $12.2 \%$ of transcription exercises. The percentages of the remaining publishing houses are: Nová škola (22,7\%), Prodos $(21,7 \%)$, SPN (19,2\%), Alter (17,6\%) Didaktis $(16,1 \%)$. In the copybooks of Nová škola, Didaktis and SPN we identified the desirable change of copying: transcription ratio, the percentage of transcription growing with every new volume of the copybook (figure 6).

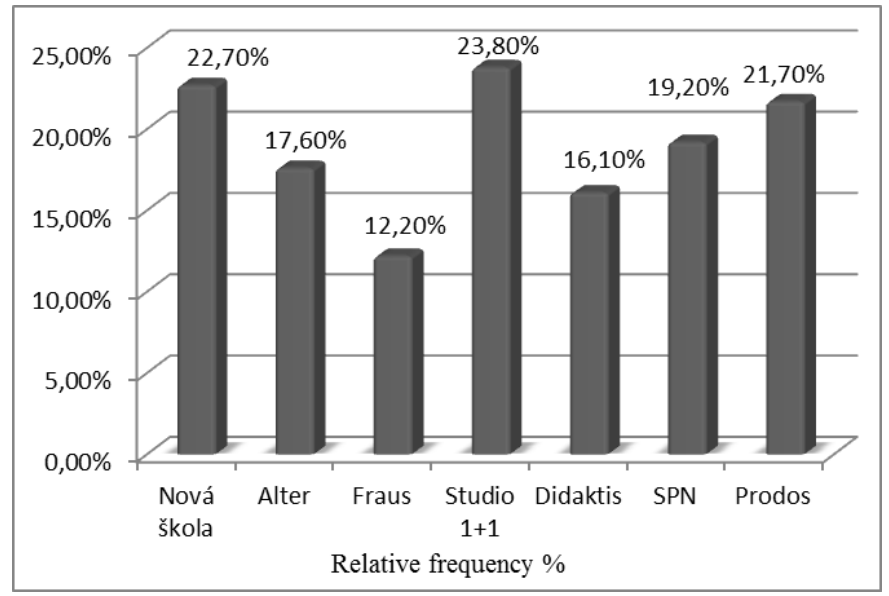

Fig. 6 Percentages of the types of exercises - transcription: copying

The graphic design of the individual editions of copybooks is an important motivation factor for the pupils. All the copybooks are decorated with more or fewer pictures in shades of grey. The publishing house Fraus adds one more colour which appears on the cover of the copybook. Despite the small surface of the coloured parts, the pictures are more marked and cheerful. Instructions are printed in the same third 
colour, which makes the pages more pleasing to the eye. The number of pictures and photos in the copybooks published by Fraus is significantly higher than in the others.

The last comparison selected to be presented here concerns the letters which the pupils learn to write in the first year of primary schools in the Czech Republic. The publishing houses Studio 1+1, Alter, Nová škola and Didaktis exclude the letters $q, Q, w, W, x, X$ from copybooks for the first year. Alter also excludes $\mathrm{Y}$. The rest of the publishing houses include all letters in copybooks for the first year. The table below shows the ten letters that pupils learn to write first in the order corresponding to the order in the copybooks.

TABLE I The first ten letters according to the order of acquisition

\begin{tabular}{|c|c|c|c|c|c|c|}
\hline Nová škola & Alter & $\begin{array}{c}\text { Frau } \\
\text { s }\end{array}$ & Studio $1+1$ & Didak. & SPN & Prodos \\
\hline $\mathrm{e}$ & $\mathrm{E}$ & 1 & $\mathrm{~L}$ & $\mathrm{e}$ & $\mathrm{e}$ & i \\
\hline 1 & I & $\mathrm{m}$ & E & i & $\mathrm{i}$ & $\mathrm{u}$ \\
\hline $\mathrm{m}$ & $\mathrm{U}$ & $\mathrm{p}$ & I & $\mathrm{u}$ & 1 & $\mathrm{e}$ \\
\hline $\mathrm{i}$ & M & $\mathrm{s}$ & $\mathrm{U}$ & $\mathrm{m}$ & $\mathrm{u}$ & $\mathrm{a}$ \\
\hline $\mathrm{u}$ & $\mathrm{T}$ & $\mathrm{t}$ & A & 1 & $\mathrm{~m}$ & o \\
\hline $\mathrm{a}$ & $\mathrm{L}$ & $\mathrm{e}$ & $\mathrm{O}$ & $\mathrm{s}$ & $\mathrm{s}$ & $\mathrm{m}$ \\
\hline $\mathrm{s}$ & A & $\mathrm{j}$ & M & $\mathrm{p}$ & $\mathrm{t}$ & $\mathrm{j}$ \\
\hline o & $\mathrm{O}$ & $\mathrm{i}$ & $\mathrm{T}$ & $\mathrm{t}$ & $\mathrm{p}$ & 1 \\
\hline $\mathrm{p}$ & $S$ & $\mathrm{n}$ & $\mathrm{P}$ & $\mathrm{j}$ & $\mathrm{j}$ & $\mathrm{s}$ \\
\hline $\mathrm{t}$ & $P$ & $\mathrm{u}$ & $\mathrm{S}$ & $\mathrm{a}$ & $\mathrm{a}$ & $\mathrm{v}$ \\
\hline
\end{tabular}

Nová škola, Alter and Studio $1+1$ all begin with the same ten letters. The order of the first four letters is the same in Alter and Didaktis, the letters being $e, i, u, m$. The letter which is usually taught first is $e$.

\section{Summary}

The results presented above identify the areas in which the individual editions of copybooks differ as well as the indicators guiding the selection of a specific edition by the respondents. Since those are primary school teachers working with the workbooks on a daily basis, we consider the findings useful and interesting.

Almost one half of the respondents use the copybooks from Nová škola. The copybooks of Alter come next with 14 $\%$, followed by Fraus with $7 \%$. More than one quarter of the respondents purchase the copybooks from the same publishing house as primers and readers (Nová škola). Almost all of the respondents are satisfied with the workbooks. As for propositions of improvement, the teachers would mainly like to add several more lines for practice of letters and words.

The sets of copybooks comprise four or five volumes; the first one is usually dedicated to relaxation exercises and has a larger format. Relaxation exercises are marginal in copybooks by Fraus and SPN is the only publishing house who has a relaxation exercise book in A5 format. Didaktis has the highest average page count, however, there are only four volumes in the set. The most popular edition published by Nová škola has the average page count of 38 pages but there are five volumes.

An interesting finding concerns the ratio of copying and transcription in the course of the $1^{\text {st }}$ year of primary schools. Most publishing houses gradually increase the percentage of transcription, however, it never exceeds $25 \%$. We consider this ratio to be optimal, the difficulty level being adequate to the stage of writing skills practice.

\section{Conclusion}

The results showed that Czech market offers a wide selection of workbooks for elementary writing practice. Pedagogues select the material according to the content and didactic qualities, sufficient volume and graphic design and they tend to purchase primers and readers from the same publishing house to maintain the consistency. We believe that these are appropriate criteria of selection. Moreover, since the differences between the individual editions are not very marked and all the sets are methodologically satisfactory it is possible to use any of the editions. Naturally, we take into account the knowledge that copybooks in larger formats (A4) are more suitable for writing practice.

This paper presents results of the Specific Research Project of University of Hradec Králové number 15 named: Comparative Analysis of Copybooks (font) used in the Czech Republic and in selected European countries.

\section{References}

[1] Euridice. Key data on education in Europe 2012. Brussels: Euridice, 2012.

[2] Kropáčková, Jana, Kucharská, Anna, Wildová, Radka. Pojetí a rozvoj čtenářské pregramotnosti $\mathrm{v}$ předškolním období (The Conception and Development of Reading Literacy in Pre-school Age). Pedagogická orientace (Pedagogic orientation), 24(4), pp.448-508. ISSN 12114669, 2014.

[3] Bielaková, Kateřina. Učebnice pro výuku elementárního čtení (Textbooks for Teaching Elementary reading). Brno: PdF, 2010.

[4] Maňák, Josef, Knecht, Petr. Hodnoceni učebnic. Brno: Paido. ISBN 978-80-7315-148-5, 2007.

[5] Janík, Tomáš, Maňák, Josef, Knecht, Petr. Cíle a obsahy školního vzděláváni a metodologie jejich utváreni (The Goals of Education, School Curriculum and the Methods of their Formation). Brno: Paido. ISBN 978-80-7315-194-2, 2010.

[6] Košek Bartošová, Iva, Plovajková Anna, Podnecká Tereza.Development of Reading Literacy Based on the Work of Textbooks (Workbooks). Procedia - Social and Behavioral Sciences, vol. 171, pp. 668-679. ISSN 1877-0428, 2015.

[7] Skutil, M. a kol. Základy pedagogicko-psychologického výzkumu pro studenty učitelství (The Basics of Pedagogico-psychological Research for Student Teachres). Praha: Portál, p. 256. ISBN 978-80-7367-778-7, 2011. 